\title{
Can the quick Sequential Organ Failure Assessment (qSOFA) score, combined with plasma lactate concentration, predict the mortality for patients with infections in the emergency department?
}

\author{
Hızlı Sofa skorunun plazma laktat konsantrasyonu ile birlikte kullanımı acil serviste enfeksiyon \\ hastalarındaki mortaliteyi öngörebilir mi?
}

\section{Mustafa Korkut $^{1}$, Cihan Bedel ${ }^{1}$}

\begin{abstract}
Aim: Few studies have looked at the predictive role of plasma lactate measure combined with the score of quick sequential organ failure assessment (qSOFA) on hospital mortality. The aim of the study was to investigate whether the score of qSOFA combined with plasma lactate is independently associated with in-hospital mortality among patients with infections in the emergency department (ED).

Methods: Scores of qSOFA and plasma lactate measurements of 60 patients in ED were collected prospectively from May 2017 to March 2018. We used the area under receiver operating characteristic curve (AUC) and sensitivity analysis to compare the applicability of qSOFA score alone and qSOFA score combined with lactate level for patient mortality.

Results: Thirteen patients $(21.6 \%)$ died in the hospitalization period. According to the qSOFA alone, qSOFA score combined with lactate measurement was more successful (AUC $=0.798$ vs. $0.885 \mathrm{p}<0.001$, respectively). When qSOFA was used alone, sensitivity and specificity were $92 \%$ and $54 \%$, otherwise those of the combined with lactate measurement were $100 \%$ and $43 \%$, respectively $(\mathrm{p}<0.001)$.

Conclusion: Combining the qSOFA with lactate has higher sensitivity for patient mortality than that seen with qSOFA alone.
\end{abstract}

Keywords: qSOFA, lactate, mortality

Öz

Amaç: Hızlı SOFA skorunun plazma laktat düzeyi ile birlikte kullanımının hastane içi mortaliteyi öngörmedek rolü ile ilgili çok az çalışma vardır. Bu çalışmamızın amacı plazma laktat düzeyi ile kombine bir hızlı SOFA skorunun, acil serviste enfeksiyonlu hastalarda hastane içi mortalite için ilişkili olup olmadığını araştırmaktı.

Yöntemler: Mayıs 2017- Mart 2018 tarihleri arasında acil servise başvuran 60 hastanın qSOFA ve plazma laktat ölçümleri prospektif olarak toplandı. Olguların qSOFA skorunun tek başına ve laktat ile birlikte kullanımının mortaliteyi öngörmedeki analizi yapıldı.

Bulgular: On üç hasta $(\% 21,6)$ hastaneye yatış süresinde öldü. Laktat ölçümü ile kombine edilmiş qSOFA qSOFA skoru tek başına kullanımına göre daha başarılı bulunmuştur (sırasıyla AUC $=0,798$ ve 0,885, sırasıyla $\mathrm{p}<0,001)$. qSOFA için tek başına duyarlılık ve özgüllük \%92 ve \%54 iken, laktat ile kombine edilmesiyle sirasıyla $\% 100$ ve $\% 43$ olduğu saptandı $(\mathrm{p}<0,001)$.

Sonuç: qSOFA'nın laktat ile kombine edilmesi, qSOFA'nın tek başına kullanılmasına göre mortalite üzerinde daha yüksek hassasiyete sahiptir.

Anahtar kelimeler: qSOFA, laktat, mortalite
1 Health Science University Antalya Training and Research Hospital, Department of Emergency Medicine, Antalya, Turkey.

Ethics Committee Approval: The study wass approved by the local ethical authority.

Etik Kurul Onayı: Çalışma lokal etik komite tarafından onaylanmıştır.

Conflict of Interest: No conflict of interest was declared by the authors.

Çıkar Çatışması: Yazarlar çıkar çatışması bildirmemişlerdir.

Financial Disclosure: The authors declared that this study has received no financial support.

Finansal Destek: Yazarlar bu çalışma için finansal destek almadıklarını beyan etmişlerdir.

Geliş Tarihi / Received: 07.10.2018

Kabul Tarihi / Accepted: 13.02.2019

Yayın Tarihi / Published: 15.03.2019

Sorumlu yazar / Corresponding author:

Cihan Bedel

Health Science University Antalya Training And Research Hospital, Kazım Karabekir Street postal zip code: 07100, Muratpaşa, Antalya, Turkey. e-posta: cihanbedel@hotmail.com Tel/Phone: +905075641254

Copyright (C) ACEM 


\section{Introduction}

Recently, the description of sepsis changed and qSOFA is recommended as a new classification system [1]. The qSOFA criteria for sepsis include an altered mental status (AMS), systolic blood pressure (SBP) less than or equal to $100 \mathrm{~mm} / \mathrm{Hg}$ and respiratory rate (RR) greater than or equal to 22 per minute (calculated by assigning 1 point each to yield a score value between 0 and 3). In the original study, the qSOFA score was useful to predict mortality and it was superior than that of the more complicated SOFA score [2]. Lactate is known as an independent indicator of mortality in septic shock and as an available marker of cellular and metabolic stress [3].

Higher serum plasma lactate measurements are correlated with enhancement morbidity and mortality in various patient samples, including $[4,5]$. When lactate level $\geq 2 \mathrm{mmol} /$ $\mathrm{L}$ was combined with the score of qSOFA, the mortality raised but serum lactate measurement did not supply statistics verges [2]. Otherwise, only limited number of studies investigated the predictive role of qSOFA in combination with plasma lactate levels in hospital mortality (Lactate $\geq 2 \mathrm{mmol} / \mathrm{L}$ adds qSOFA enhances efficacy over qSOFA alone in the ED patients with suspected sepsis). Our purpose for this study was to investigate whether combining qSOFA with plasma lactate concentration is independently correlated with in-hospital mortality among patients who were admitted to the ED with infections.

\section{Material and methods}

The present research was a single center study and the samples were observed prospectively. Our population was the patients with clinically suspected or diagnosed infection at the ED from May 2017 to March 2018. Our hospital is a 2000-bed education and research hospital with about 360000 ED visitors per year. This study was approved by the ethics committee of our institution. Informed consent documents were taken from all the patients. The study was performed following the Helsinki Declaration.

Our inclusion criteria for this study were being $\geq 18$ years, with infection diagnosed or suspected by an emergency physician, and admitted to the ED. Pneumonia was diagnosed through chest radiography with two or more symptoms of dyspnea, fever, cough, sputum, breathlessness and/or pleuritic chest pain. Inflammatory markers such as C-reactive protein and leukocyte count were used for the diagnosis of infection [6]. Intra-abdominal infections were defined within any abdominal organ or cavity, containing radiographic or imaging indication of infection and one or more of such symptoms as fever, nausea, vomiting, abdominal pain or jaundice. Other infections contained skin and soft tissue infections, cerebral infection, and pyelonephritis. A qSOFA score $\geq 1$ was included in this study. During the study period, 96 adults were admitted with suspected infection, 60 patients $(62.5 \%)$ who met the inclusion criteria were included in the final analysis. A total of 36 patients were excluded from the study; 12 of these patients were missing data and 24 patients were excluded from the study with exclusion criteria (Figure 1).

The exclusion criteria were respectively: age $<18$ years $(n=2)$, a qSOFA score $<1 \quad(n=3)$, trauma $(n=2)$, cardiac arrest $(\mathrm{n}=2)$, aortic dissection $(\mathrm{n}=1)$, acute pulmonary thromboembolism $(n=1)$, acute cardiac failure $(n=2)$, end stage malignant diseases $(n=3)$, burns $(n=1)$, human immunodeficiency virus positivity $(n=1)$, intubated patients $(n=1)$, use of immunosuppressant drugs $(n=1)$. Those admitted for palliative therapies $(n=2)$, and patients who refused to participate $(n=2)$ in the study were also excluded.

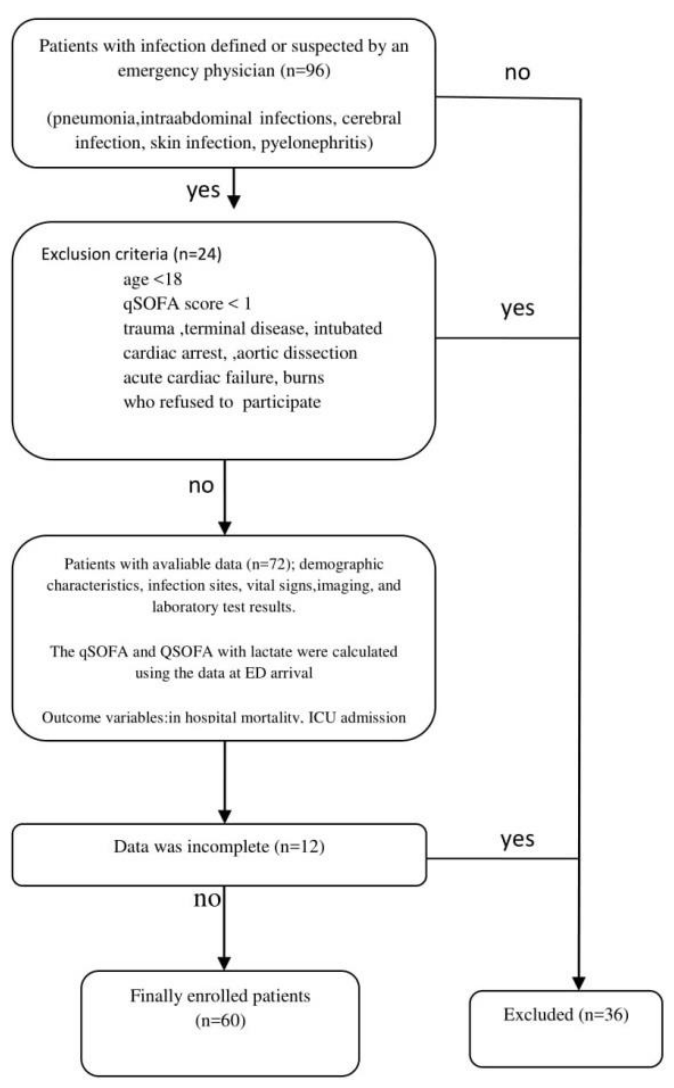

Figure 1: Flowchart of patient enrollment.

After application to triage in ED, we collected demographic status, focus of infection, vital signs, radiographic imaging and laboratory test results of registered patients. We first calculated the qSOFA score (within 2 minutes or less) within a range of 0 to 3 . This score was calculated according to values of systolic blood pressure (SBP) less than or equal to $100 \mathrm{~mm} / \mathrm{Hg}$ and respiratory rate (RR) greater than or equal to 22 per minute and any alteration of mental status (calculated by assigning 1 point each to yield a score value between 0 and 3). The emergency physician assessed the state of consciousness of the patient, where patients with Glasgow coma score <15 were accepted as altered mental status (AMS). AMS also included any altered mentation such as somnolence and disorientation. Plasma lactate levels stabilized during the patient's first hour in the ED We measured lactate levels of patients after the first hour. For the patients whose plasma lactate levels were $\geq 2 \mathrm{mmol} / \mathrm{L}$, one additional point was added to the score of patient's qSOFA. qSOFA+lactate (qSOFA score with plasma lactate score) scores were calculated within the range of 0 to 4 . We compared the effect of these measurements on mortality. In our study, the primary outcome was about hospital mortality. Secondary outcomes were about hospital admission, ICU admission, and total length of stay at the hospital, from ED triage to discharge from the hospital.

\section{Statistical analysis}

We used SPSS software version 20.0 (SPSS, Inc, Chicago, IL) for all statistical analyses. Normally distributed data were given as means \pm standard deviations. We compared normally distributed variables using the independent-samples $t$ test. Data with does not have normal distribution were presented 
as median and quartiles, which we analyzed by using MannWhitney $U$ test. We compared categorical variables using $\chi 2$ statistics. The independent variables of outcomes that statistical significance evaluated by logistic regression analysis. We tested all variables with statistical difference in a binary logistic analysis together with qSOFA. We formed receiver operating characteristic (ROC) curves and evaluated the AUC to define predictive values. We also calculated prognostic parameters (sensitivity and specificity). All statistical tests were two-tailed, and $\mathrm{p}<0.05$ was considered significant.

\section{Results}

Ninety-six patients were asked to fill in the study data forms for the study. Thirty six patients who fulfill one or more of the exclusion criteria were excluded from the study (Figure 1). Of the 60 patients included in the study, $41(68.3 \%)$ were female and $19(63 \%)$ were male. The mean age of the patients was $67.23 \pm 16.75$ years. Of the patients, 47 patients $(78.4 \%)$ survived and 13 patients $(21.6 \%)$ died during hospitalization. Cardiovascular disease was the most common cause of comorbidities of the patients in $18(30 \%)$ followed by chronic obstructive lung disease in $16(26.7 \%)$, diabetes mellitus and immunosuppression diseases in 11 (18.3\%). Baseline population characteristics are shown in Table 1.

A SBP $\leq 100 \mathrm{mmHg}$ and a $\mathrm{RR} \geq 22$ breaths/min were founded at $29(48.33 \%)$ and $53(88.33 \%)$ of the patients, respectively. 14 (23.33) of the patients were AMS cases. Higher lactate measurements, qSOFA and qSOFA combined lactate scores were statistically significant in the dead patients (Table 2).

\begin{tabular}{|c|c|c|c|c|}
\hline Variable & $\begin{array}{l}\text { Overall } \\
(\mathrm{n}=60)\end{array}$ & $\begin{array}{l}\text { Alive } \\
(\mathrm{n}=47)\end{array}$ & $\begin{array}{c}\text { Dead } \\
(\mathrm{n}=13)\end{array}$ & $\mathrm{p}$ \\
\hline Sex (Female/male) & $41 / 19$ & $30 / 17$ & $11 / 2$ & 0.194 \\
\hline Age (year) ${ }^{\#}$ & $67.23 \pm 16.75$ & $66.36 \pm 18.05$ & $70.38 \pm 10.38$ & 0.443 \\
\hline Comorbidities & & & & \\
\hline Diabetes mellitus $^{¥}$ & $11(18.3)$ & $7(14.8)$ & $4(30.7)$ & 0.231 \\
\hline $\begin{array}{l}\text { Chronic obstructive lung } \\
\text { disease }^{¥}\end{array}$ & $16(26.7)$ & $15(31.9)$ & $1(7.7)$ & 0.153 \\
\hline Chronic renal disease $^{*}$ & $9(15)$ & $6(12.7)$ & $3(23.1)$ & 0.392 \\
\hline Chronic liver disease $^{*}$ & $4(6.7)$ & $2(4.2)$ & $2(15.4)$ & 0.202 \\
\hline Cardiovascular disease $e^{x}$ & $18(30)$ & $12(25.5)$ & $6(46.2)$ & 0.181 \\
\hline Immunosuppression ${ }^{¥}$ & $11(18.3)$ & $4(8.5)$ & $7(53.8)$ & 0.001 \\
\hline Life style changes in the urban ${ }^{*}$ & $44(73.3)$ & $35(79.6)$ & $9(20.4)$ & 0.560 \\
\hline Infection focus & & & & \\
\hline Pneumonia $^{*}$ & $28(46.7)$ & $23(48.9)$ & $5(38.4)$ & 0.547 \\
\hline Intraabdominal infection $^{*}$ & $10(16.7)$ & $5(50)$ & $5(50)$ & 0.017 \\
\hline Urinary tract infection ${ }^{*}$ & $11(18.3)$ & $9(19.2)$ & $2(15.4)$ & 0.557 \\
\hline Others ${ }^{*}$ & $11(18.3)$ & $9(19.2)$ & $2(15.4)$ & 0.557 \\
\hline Blood culture positive ${ }^{x}$ & $10(16.6)$ & $8(17)$ & $2(15.4)$ & 0.384 \\
\hline Urine culture positive & $5(8.4)$ & $4(8.5)$ & $1(7.6)$ & 0.716 \\
\hline Sputum culture positive ${ }^{*}$ & $3(5)$ & $2(4.2)$ & $1(7.6)$ & 0.394 \\
\hline ICU admission ${ }^{*}$ & $20(33.3)$ & $10(21.2)$ & $10(76.9)$ & $<0.001$ \\
\hline $\begin{array}{l}\text { LOS in hospital median, } \leq 10 \\
\text { days }\end{array}$ & $40(66.7)$ & $28(70)$ & $12(30)$ & 0.027 \\
\hline $\begin{array}{l}\text { Discharge from emergency } \\
\text { department }\end{array}$ & $11(18.3)$ & $11(100)$ & $0(0)$ & 0.054 \\
\hline
\end{tabular}

This study investigated the effectiveness of the qSOFA, lactate and the combining score (qSOFA with lactate) for the prediction of the mortality using ROC analysis. It was found that the area under curve (AUC) values of these variables were statistically significant to predict mortality (Table 3; Figure 2). qSOFA with lactate had the highest AUC $(0.885 ; \mathrm{p}<<.001)$ followed by qSOFA and lactate (AUC $=0.798 ; \mathrm{p}=0.790$, respectively). Moreover, the combining score had a higher sensitivity with a little alteration in specificity compared with that of the qSOFA score alone. In our study, when the qSOFA score was compared with lactate levels for the prediction of the mortality; qSOFA had the lower specificity (54\%), though it had the higher sensitivity (92\%) with a AUC value of 0.798 (Table $3)$.
Table 2. Distribution of lactate levels and qSOFA, qSOFA + lactate scores.

\begin{tabular}{lcccc}
\multicolumn{1}{c}{ Variable } & $\begin{array}{c}\text { Overall } \\
(\mathrm{n}=60)\end{array}$ & $\begin{array}{c}\text { Alive } \\
(\mathrm{n}=47)\end{array}$ & $\begin{array}{c}\text { Dead } \\
(\mathrm{n}=13)\end{array}$ & $\mathrm{p}$ \\
\hline Lactate, $\mathrm{mmol} / \mathrm{L}^{\#}$ & $2.15 \pm 2.3$ & $1.55 \pm 1.28$ & $4.32 \pm 3.65$ & $<0.001$ \\
Lactate $\geq 2.0 \mathrm{mmol} / \mathrm{L}^{*}$ & $17(28.3)$ & $9(19.1)$ & $8(61.5)$ & $<0.001$ \\
qSOFA Score & $1.65 \pm 0.63$ & $1.49 \pm 0.54$ & $2.23 \pm 0.59$ & $<0.001$ \\
qSOFA $^{*}$ & & & & $<0.001$ \\
1 & $26(43.3)$ & $25(53.2)$ & $1(7.7)$ & \\
2 & $29(48.4)$ & $21(44.7)$ & $8(61.5)$ & \\
3 & $5(8.3)$ & $1(2.1)$ & $4(30.8)$ & \\
qSOFA + lactate score ${ }^{*}$ & & & & $<0.001$ \\
1 & $20(33.3)$ & $20(42.6)$ & $0(0)$ & \\
2 & $25(41.7)$ & $22(46.8)$ & $3(23.1)$ & \\
3 & $14(23.3)$ & $5(10.6)$ & $9(69.2)$ & \\
4 & $1(1.7)$ & $0(0)$ & $1(7.7)$ & \\
\hline${ }^{\#}:$ mean $\pm \mathrm{SD},{ }^{*}: \mathrm{n}(\%)$. & & & &
\end{tabular}

Table 3. Receiver operating characteristics analysis of each parameter for the prediction of mortality.

\begin{tabular}{lcccc} 
Variable & Sensitivity $^{\mu}$ & Specificity $^{\mu}$ & AUC $^{\mu}$ & $\mathrm{p}$ \\
\hline Lactate & $61(32-86)$ & $81(67-91)$ & $0.790(0.650-0.925)$ & $<0.001$ \\
qSOFA & $92(64-99)$ & $54(38-68)$ & $0.798(0.654-0.945)$ & $<0.001$ \\
qSOFA +lactate & $100(76-100)$ & $43(28-58)$ & $0.885(0.789-0.980)$ & $<0.001$ \\
\hline \multicolumn{4}{l}{ qSOFA: quick sequential organ failure assessment, AUC: area under curve, ${ }^{\mu}$ : mean (range). }
\end{tabular}

Figure 2. Receiver operation characteristic curve for patient mortality using qSOFA alone and QSOFA with lactate score. The combined qSOFA and lactate level score has a higher AUC than qSOFA alone (AUC $=0.885$ vs. $0.798, \mathrm{p}<0.001$, respectively). $\mathrm{AUC}=$ area under curve, qSOFA = quick Sequential Organ Failure Assessment

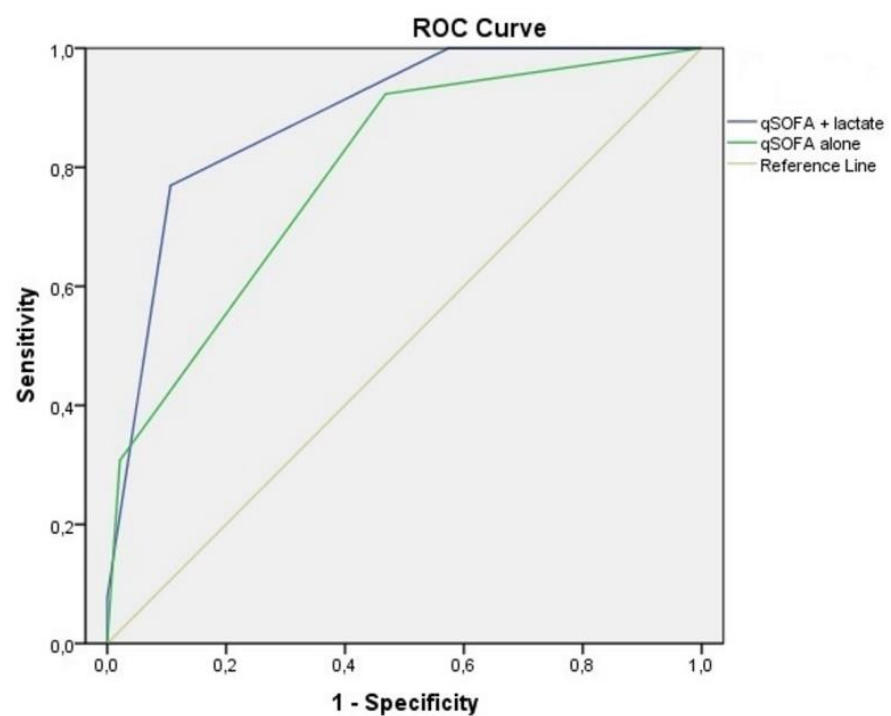

Figure 2. Receiver operation characteristic curve for patient mortality using qSOFA alone and QSOFA with lactate score. The combined qSOFA and lactate level score has a higher AUC than qSOFA alone (AUC $=0.885$ vs. 0.798 , $\mathrm{p}=0.001$, respectively). AUC $=$ area under curve, $\mathrm{qSOFA}=$ quick Sequential Organ Failure Assessment.

\section{Discussion}

Our findings proved that only the qSOFA has higher sensitivity. It was a mild predictive performance. In contrast to our study, the literature found poor sensitivity with qSOFA scores, which created a growing concern. The risk of in-hospital mortality increases if resuscitation delays in the ED [7]. qSOFA with lactate resulted in enhanced sensitivity with a vaguely decreased specificity. In a study presented in ED structured by Williams et al. $26.8 \%$ had a SBP $\leq 100 \mathrm{mmHg}, 21.1 \%$ of patients had a RR $\geq 22$ breaths/min and only $5.1 \%$ of patients had AMS [8]. This study also showed that only 14 patients (\% 23.3) in this study sample (60 patients) had AMS. Among patients applied to the ED with AMS, only 13 (92.85\%) of our patients had a qSOFA score $\geq 2$, which makes it complicated to investigate. Thus, identifying patient's mortality risk increased. In our study group, one patient had a qSOFA score $<2$ and died. 
Other studies presented that qSOFA had poor sensitivity, so that it was not useful for the screening test for sepsis $[8,9]$.

We found that qSOFA and qSOFA with lactate scores were significantly correlated with all measured outcomes, including in hospital mortality, intensive care unit (ICU) admission and hospitalization. In this study, the qSOFA score performed well in showing mortality for the patients with suspected infection. Therefore, the qSOFA score, easily calculated in consent with vital signs, can be used as a generic scale to predict clinically important outcomes for ED patients. ED patients covered in the study are likely to be admitted regardless of whether mortality is suspected. qSOFA score of 2 or greater had higher sensitivity. Besides this, a qSOFA score of $<2$ had perfect negative predictive value, with high sensitivity and specificity. The performance of the qSOFA in our study was similar to that of more complex scores such as the mortality in ED sepsis score originally derived by Shapiro et al. [10]. In this study, the AUC for the score was 0.82 and more advanced prediction scores were declared to have even greater accuracy [11]. The superiority of the qSOFA score is its simplicity and the fact that it can be calculated without any laboratory tests.

We analyzed combination scores containing qSOFA and plasma lactate measurement. As recommended in many studies, plasma lactate level is a significant predictor of mortality in seriously critical patients $[12,13]$. In contrast to the literature, only plasma lactate level with a cutoff value of $2 \mathrm{mmol} / \mathrm{L}$ showed a well predictive performance, but when combined with qSOFA, its efficacy of predictive value in-hospital mortality was lower in our study population.

The rapid point-of-care (POC) measurement blood lactate level is practical, feasible, and reliable. Singer et al. [14] recorded that bedside POC lactate measurement in adult ED patients decrease time to administration of septic patients, leading to a decrease of in hospital mortality for these patients. Combined lactate levels with qSOFA score increases qSOFA's discriminating power and can be used as a rapid and simple method. Recently Seymour et al. [2] have reported the predictive value of qSOFA for inpatient mortality within ICU encounters was 0.66 (95\% CI 0.64 to 0.68 ). The predictive value within nonICU encounters was 0.81 (95\% CI 0.80 to 0.82$)$. This was statistically significant unlike the results for SOFA or systemic inflammatory response syndrome criteria [2]. In contrast to the literature, our finding qSOFA with lactate had the highest AUC (0.885) followed by qSOFA and lactate (AUC=0.798). But, qSOFA with lactate had a higher sensitivity with a lower specificity compared with lactate or qSOFA score alone.

Our study has some limitations. First, our study sample was from a single center with an early quantitative resuscitation program for sepsis patients who were presented to the ED. Thus, our findings may not be widely generalizable to other centers at which resuscitation programs are not applicable for sepsis management. Second, lactate was not simultaneously measured in all patients valid for the study. Third, due to the small population, there may have been inadequate statistical power to identify some of the significant findings.

As a result, in the ED using only the qSOFA score has poor sensitivity for screening patients with high risk of mortality. Combining the qSOFA with lactate has higher sensitivity for patient mortality than that seen with qSOFA alone.

\section{References}

1. Singer M, Deutschman CS, Seymour CW, Shankar-Hari M, Annane D, Bauer M, et al. The third international consensus definitions for sepsis and septic shock. JAMA. 2016;315:801-10.

2. Seymour CW, Liu VX, Iwashyna TJ, Brunkhorst FM, Rea TD, Scherag A, et al. Assessment of clinical criteria for sepsis: for the Third
International Consensus Definitions for Sepsis and Septic Shock. JAMA. 2016;315:762-74.

3. Casserly B, Phillips GS, Schorr C, Dellinger RP, Townsend SR, Osborn TM, et al. Lactate measurements in sepsis-induced tissue hypoperfusion: results from the Surviving Sepsis Campaign database. Crit Care Med. 2015;43:567-73.

4. Mikkelsen ME, Miltiades AN, Gaieski DF, Goyal M, Fuchs BD, Shah $\mathrm{CV}$, et al. Serum lactate is associated with mortality in severe sepsis independent of organ failure and shock. Crit Care Med. 2009;37:1670-7.

5. Del Portal DA, Shofer F, Mikkelsen ME, Dorsey Jr PJ, Gaieski DF, Goyal M, et al. Emergency department lactate is associated with mortality in older adults admitted with and without infections. Acad Emerg Med. 2010;17:260-8.

6. Mandell LA, Wunderink RG, Anzueto A, Bartlett JG, Campbell GD, Dean NC, et al. Infectious Diseases Society of America/American Thoracic Society consensus guidelines on the management of community-acquired pneumonia in adults. Crit Care Med. 2007;44:2772.

7. Sartelli M, Kluger Y, Ansaloni L, Hardcastle TC, Rello J, Watkins RR, et al. Raising concerns about the Sepsis-3 definitions. World J Emerg Surg. 2018;13:6.

8. Williams JM, Greenslade JH, McKenzie JV, Chu K, Brown AF, Lipman J. Systemic inflammatory response syndrome, quick sequential organ function assessment, and organ dysfunction: insights from a prospective database of ED patients with infection. Chest. 2017;151:586-96.

9. Dorsett M, Kroll M, Smith CS, Asaro P, Liang SY, Moy HP. qSOFA has poor sensitivity for prehospital identification of severe sepsis and septic shock. Prehosp Emerg Care. 2017;21:489-97.

10. Shapiro NI, Wolfe RE, Moore RB, Smith E, Burdick E, Bates DW. Mortality in Emergency Department Sepsis (MEDS) score: a prospectively derived and validated clinical prediction rule. Crit Care Med. 2003;31:670-5.

11. Singer AJ, Ng J, Thode Jr HC, Spiegel R, Weingart S. Quick SOFA scores predict mortality in adult emergency department patients with and without suspected infection. Ann Emerg Med. 2017;69:475-9.

12. Chebl RB, El Khuri C, Shami A, Rajha E, Faris N, Bachir R, et al. Serum lactate is an independent predictor of hospital mortality in critically ill patients in the emergency department: a retrospective study. Scand J Trauma Resusc Emerg Med. 2017;25:69.

13. Lokhandwala S, Andersen LW, Nair S, Patel P, Cocchi MN, Donnino MW. Absolute lactate value vs relative reduction as a predictor of mortality in severe sepsis and septic shock. J Crit Care. 2017;37:179-84.

14. Shapiro NI, Fisher C, Donnino M, Cataldo L, Tang A, Trzeciak S, et al. The feasibility and accuracy of point-of-care lactate measurement in emergency department patients with suspected infection. J Emerg Med. 2010;39:89-94. 